\title{
The Effect of Wildfire on Soil Mercury Concentrations in Southern California Watersheds
}

\author{
Megan P. Burke • Terri S. Hogue • \\ Marcia Ferreira $\cdot$ Carolina B. Mendez • \\ Bridget Navarro $\cdot$ Sonya Lopez $\cdot$ Jennifer A. Jay
}

Received: 30 July 2009 /Accepted: 2 February 2010/Published online: 16 March 2010

(C) The Author(s) 2010. This article is published with open access at Springerlink.com

\begin{abstract}
Mercury ( $\mathrm{Hg})$ stored in vegetation and soils is known to be released to the atmosphere during wildfires, increasing atmospheric stores and altering terrestrial budgets. Increased erosion and transport of sediments is well-documented in burned watersheds, both immediately post-fire and as the watershed recovers; however, understanding post-fire mobilization of soil $\mathrm{Hg}$ within burned watersheds remains elusive. The goal of the current study is to better understand the impact of wildfire on soil-bound $\mathrm{Hg}$ during the immediate postfire period as well as during recovery, in order to assess the potential for sediment-driven transport to and within surface waters in burned watersheds. Soils were collected from three southern California watersheds of similar vegetation and soil characteristics that experienced wildfire. Sampling in one of these watersheds was extended for several seasons (1.5 years) in order to investigate temporal changes in soil $\mathrm{Hg}$ concentrations. Laboratory analysis included bulk soil total $\mathrm{Hg}$ concentrations and total organic carbon of burned and unburned samples. Soils were also fractionated into a subset of grain sizes with analysis of $\mathrm{Hg}$ on each fraction. Low $\mathrm{Hg}$ concentrations were observed in surface soils immedi-
\end{abstract}

M. P. Burke $(\bowtie) \cdot$ T. S. Hogue $(\bowtie) \cdot$ M. Ferreira $\cdot$

C. B. Mendez $\cdot$ B. Navarro $\cdot$ S. Lopez $\cdot$ J. A. Jay

Department of Civil and Environmental Engineering,

UCLA,

5731F Boelter Hall,

Los Angeles, CA 90095-1593, USA

e-mail: megaburke@ucla.edu

e-mail: thogue@seas.ucla.edu ately post-fire. Accumulation of $\mathrm{Hg}$ coincident with moderate vegetative recovery was observed in the burned surface soils 1 year following the fire, and mobilization was also noted during the second winter (rainy) season. $\mathrm{Hg}$ concentrations were highest in the fine-grained fraction of unburned soils; however, in the burned soils, the distribution of soil-bound $\mathrm{Hg}$ was less influenced by grain size. The accelerated accumulation of $\mathrm{Hg}$ observed in the burned soils, along with the elevated risk of erosion, could result in increased delivery of organic- or particulate-bound $\mathrm{Hg}$ to surface waters in post-fire systems.

Keywords Mercury · Soil · Fire · California ·

Semi-arid · Chaparral

\section{Introduction}

Southern California, with its Mediterranean climate of winter rains and long dry summers, has a fire regime characterized by periodic, and sometimes deadly, wildfires, exacerbated by land use patterns (urban/ wild-land encroachment) and a warming climate (Whitlock 2004; Westerling et al. 2006; Keeley and Zedler 2009; CDFFP 2007; Westerling and Bryant 2008). Besides the immediate threat from active wildfires, post-fire watershed conditions raise additional concerns for flooding and debris flows (Cannon et al. 1998, 2001; Cannon and Reneau 2000; Morales et al. 2000; Moody and Martin 2001; Beeson et al. 
2001; Gabet 2003; Wondzell and King 2003). Fires are also known to alter stream chemistry (Chorover et al. 1994; Stephens et al. 2005; Meixner et al. 2006; Jung et al. 2009; Mast and Clow 2008), and post-fire storm events have the capacity to carry large sediment loads, mobilizing and transporting heavy metals and other contaminants (Desilets et al. 2007; Rulli and Rosso 2007; Pierson et al. 2008). Of particular concern is the potential movement of mercury $(\mathrm{Hg})$ into downstream water bodies, where conditions may be conducive for the formation of methyl mercury $(\mathrm{MeHg})$, a potent neurotoxin with a strong tendency to bio-magnify within the food chain (Caldwell et al. 2000; Amirbahman et al. 2004; Kelly et al. 2006). However, there is a paucity of data on the impact of wildfire on $\mathrm{Hg}$-soil behavior, which we advocate is critical for the assessment and potential modeling of post-fire $\mathrm{Hg}$ transport to surface waters.

Recent studies indicate volatilization of $\mathrm{Hg}$ (from vegetation, litter, soils, etc.) during wildfire is an important pathway for the re-emission of atmospherically deposited Hg (Harden et al. 2004; Brunke et al. 2001; Friedli et al. 2001; Friedli et al. 2003a; Friedli et al. 2003b; Sigler et al. 2003; Mailman and Bodaly 2005; Engle et al. 2006; Biswas et al. 2007; Dicosty et al. 2006). Observed losses of $\mathrm{Hg}$, using airborne measurements in smoke plumes or National Atmospheric Deposition Program data, have been used to develop and cross-validate $\mathrm{Hg}$ emission models during wildfire (Wiedinmeyer and Friedli 2007; Dicosty et al. 2006). Engle et al. (2006) noted that, although mineral soil was found to contain the largest reservoir of $\mathrm{Hg}$ in both the desert and forested sites studied, its contribution to fireinduced $\mathrm{Hg}$ emissions was relatively small compared with $\mathrm{Hg}$ released from litter and vegetation. The authors also measured higher $\mathrm{Hg}$ concentrations in surface ash 1 year following both wildfire and prescribed burns and suggest this was related to sorption of atmospheric $\mathrm{Hg}$ over the subsequent year due to Hg's high affinity for carbon in ash (Engle et al. 2006; Olson et al. 2000; Gustin and Ladwig 2004).

Elevated $\mathrm{Hg}$ levels have been found in downstream waters of burned watersheds, suggesting that the potential for enhanced mobilization of $\mathrm{Hg}$ in postfire systems persists after the initial threat of fire has passed (Caldwell et al. 2000; Amirbahman et al. 2004; Kelly et al. 2006). Kelly et al. (2006) noted a large, unexpected pulse of both total $\mathrm{Hg}(\mathrm{THg})$ and $\mathrm{MeHg}$ delivered to a reservoir system in the first post- fire storm event, underscoring that volatilization of $\mathrm{Hg}$ to the atmosphere is but one of the ways that fire enhances $\mathrm{Hg}$ transport. Fish in a downstream reservoir exhibited elevated $\mathrm{MeHg}$ concentrations that were attributed primarily to food web restructuring (Kelly et al. 2006). Caldwell et al. (2000) measured large amounts of $\mathrm{Hg}$ mobilized in creek runoff in a freshly burned mixed-conifer forest, as well as a six-fold elevation in the concentration of total $\mathrm{Hg}$ and a 30 -fold elevation in $\mathrm{MeHg}$ concentrations in the sediments of the receiving reservoir near the creek input. The authors hypothesize that particulate organic matter in post-fire runoff not only transported $\mathrm{Hg}$, but lead to downstream sediment conditions conducive to $\mathrm{Hg}$ methylation.

$\mathrm{Hg}$ transport to terrestrial waters has been associated with suspended sediments and organic matter (Ullrich et al. 2001; Ravichandran 2004). In Hgenriched sites, such as those contaminated by mining waste or industrial activities, particulate-bound $\mathrm{Hg}$ has been shown to control $\mathrm{Hg}$ flux in surface waters during storm events (Hurley et al. 1995; Babiarz et al. 1998; Mason and Sullivan 1998; Whyte and Kirchner 2000; Lawson and Mason 2001, Blake et al. 2003). At a Hg-enriched abandoned mine site in Northern California, Whyte and Kirchner (2000) reported that greater than $99.7 \%$ of the total $\mathrm{Hg}$ transported during storm events was particulate-bound. In a partially urbanized catchment draining to Chesapeake Bay, measured $\mathrm{Hg}$ concentrations three to five times higher in storms (over baseflow conditions) were attributed to particulate loading (Mason and Sullivan 1998). Recent work suggests that litterfall and throughfall, as well as the dissolved fraction of organic matter, are important factors in $\mathrm{Hg}$ transport in undisturbed watersheds, particularly where snow is the dominant form of precipitation (Bushey et al. 2008). However, suspended sediment concentration remains a controlling factor in $\mathrm{Hg}$ flux in disturbed watersheds, including those impacted by fire.

The goal of the current study is to facilitate a better understanding of soil-bound $\mathrm{Hg}$ in burned watersheds of semi-arid regions. Particular emphasis is placed on the temporal evolution of soil $\mathrm{Hg}$ profiles during the post-fire recovery period and on $\mathrm{Hg}$ partitioning within grain-size fractions. We advocate that a better understanding of these processes may ultimately facilitate modeling of sediment-driven $\mathrm{Hg}$ transport during post-fire storm events and improve predictions of potential contamination of downstream water bodies. 


\section{Methods}

\subsection{Study Sites and Sample Collection}

Mercury concentrations were determined in soils collected from three Southern California watersheds following wildfires in 2005 [Malibu Creek watershed (Topanga Fire)] and 2006 [Arroyo Seco watershed (Pines Fire) and Piru Creek watershed (Day Fire); Table 1; Fig. 1]. Preliminary investigations were conducted in the Malibu (Topanga Fire) and Arroyo Seco (Pines Fire) watersheds, and soils were only collected immediately following the wildfires. Analysis of these samples led to more extensive exploration of Piru Creek watershed (Day Fire), where field investigations included both temporal sampling of soil profiles and grain-size analysis. Piru Creek soils were collected immediately following the fire (Fall 2006) and prior to the first storm, as well as seasonally throughout 2007 and the winter of 2008. Stringent sampling protocol (Clean Hands-Dirty Hands) was followed during field collections at all three study areas. Soil samples were collected in new, acid-washed, environmental sampling bottles with Teflon-lined lids using acid-washed plastic shovels. All bottled samples were stored in double plastic bags to avoid contamination and held at $4{ }^{\circ} \mathrm{C}$ until analysis. Additional soils were collected at each study area for texture classification. Sieve and hydrometer analysis was used to separate material into sand $(2 \mathrm{~mm}-0.05 \mathrm{~mm})$, silt $(0.05 \mathrm{~mm}-$ $0.002 \mathrm{~mm})$, and clay fractions $(0-0.002 \mathrm{~mm})$, and soil texture was determined using the USDA NRCS classification system (Soil Survey Division Staff 1993).

Burn severities at each of the study areas were estimated using Moderate Resolution Imaging Spec- troradiometer (MODIS) differenced Normalized Burn Ratio (dNBR) and used to aid in the selection of sampling locations (Key and Benson 2006). This index is used by Burned Area Emergency Rehabilitation teams and the California Department of Forestry and Fire Protection to assess landscape-level fire severity. Because of the coarse spatial resolution $(1 \mathrm{~km})$ of MODIS imagery, dNBR fire severity assessments were verified with field observations, where burn severity was characterized by percent litter consumed $(>50 \%=$ low, $100 \%=$ moderate $)$ and percent foliage altered $(>30 \%=$ low, $>80 \%=$ moderate, and $>95 \%=$ high; Key and Benson 2006). Water Drop Penetration Tests (WDPT) and infiltration studies were conducted in triplicate at Malibu (Topanga Fire) and Arroyo Seco (Pines Fire) watersheds as well as at Piru Creek (Day Fire) watershed immediately post-fire to assess soil hydrophobicity (DeBano 1981). For the WDPT technique, three drops of water were place on the surface of each sampled layer and allowed to infiltrate the soil. Where all drops infiltrated in $<5 \mathrm{~s}$, the soil was classified as wettable, and where all penetration times exceeded $5 \mathrm{~s}$, the soil was classified as water-repellant (Letey 1969). Mini-disk infiltrometers were used to measure soil hydraulic conductivity at the soil surface at all three study areas. Infiltration rates measured using the mini-disk infiltrometers were used to aid in the assessment of soil hydrophobicity.

\subsubsection{Malibu Watershed (Topanga Fire)}

The Topanga Fire started on September 28, 2005, and was active until October 13, 2005. The fire burned $98 \mathrm{~km}^{2}$ in the Santa Monica Mountains along the border of Los Angeles and Ventura Counties,

Table 1 General site descriptions and sampling information for the three study areas

\begin{tabular}{|c|c|c|c|}
\hline & Malibu Creek (Topanga Fire) & Arroyo Seco (Pines Fire) & Piru Creek (Day Fire) \\
\hline Fire dates & $9 / 28 / 05-10 / 13 / 05$ & $9 / 19 / 06-9 / 23 / 06$ & $9 / 4 / 06-10 / 13 / 06$ \\
\hline Area burned & $98 \mathrm{~km}^{2}$ & $1 \mathrm{~km}^{2}$ & $660 \mathrm{~km}^{2}$ \\
\hline Annual precipitation & $450 \mathrm{~mm}$ & $840 \mathrm{~mm}$ & $480 \mathrm{~mm}$ \\
\hline Primary vegetation & Chaparral & Chaparral & Chaparral \\
\hline Dominant soil texture & Sand & Sandy loam & Sandy loam \\
\hline Bedrock & Miocene marine deposits & Miocene non-marine deposits & Permian-Triassic granite \\
\hline Number of burned sites & 4 & 4 & 6 \\
\hline Number of unburned sites & 0 & 1 & 2 \\
\hline
\end{tabular}




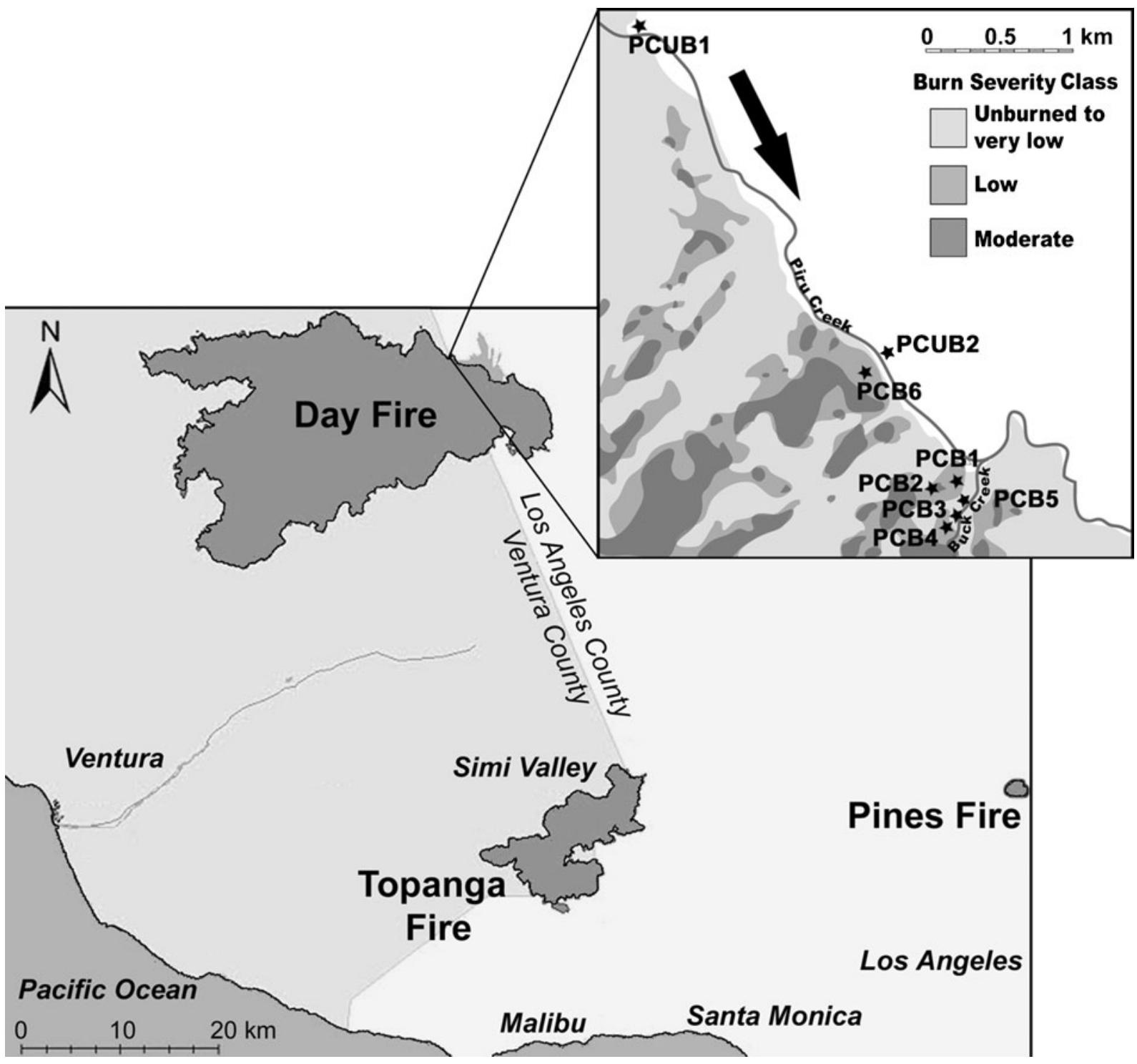

Fig. 1 Locations of the Topanga, Pines, and Day Fire study areas. The inset map shows locations, burn severity, and proximity to surface waters for the Day Fire sampling sites. A California Department of Water Resources (CADWR) stream gage is located at the confluence of Piru and Buck Creeks. Piru Creek flows into Pyramid Lake reservoir $3.2 \mathrm{~km}$ below the confluence (arrow indicates flow direction)

Malibu Canyon soils are predominantly coarse and granular in structure, but can vary greatly depending on the parent material (USDA Natural Resource Conservation Service 2007). The dominant texture of soils from the sampling locations was determined to be in the sand-sized fraction.

Soil samples were collected at four burned sites in Malibu Watershed (MB1-4). Unburned soils were not collected at this location. Two sites were sampled in Las Virgenes Canyon on Oct 14, 2005, prior to any 
precipitation (MB1, MB2), and two sites were sampled in Malibu Canyon on Nov 4, 2005, after the first postfire storm (MB3, MB4). The Las Virgenes soils were collected at a depth of $2.5 \mathrm{~cm}$; Malibu Canyon soils were sampled at 2.5- and 10-cm depths, with approximately $50 \mathrm{~g}$ of soil collected at each depth interval. Three samples were collected at each of the Malibu Canyons sites to account for spatial variability. Soils were analyzed for THg and total organic carbon (TOC).

\subsubsection{Arroyo Seco Watershed (Pines Fire)}

The Pines Fire occurred in the headwaters of the Arroyo Seco watershed, located on the eastern edge of Los Angeles County in the San Gabriel Mountains (Fig. 1). The fire started September 19, 2006, and was contained by September 23, consuming only $\sim 1 \mathrm{~km}^{2}$ (Table 1). The San Gabriel Mountains are located on the northeastern edge (windward) of the Los Angeles basin and are known to have high deposition rates of urban pollutants originating from the metropolitan region (Barco et al. 2008). Previous work on the upper Arroyo Seco revealed significant nutrient and other chemical loads contributing to downstream (urban) water bodies (Barco et al. 2008). We hypothesize that fire in these urban-fringe watersheds may exacerbate existing water quality problems and increase downstream chemical loads (US EPA 2007). The upper Arroyo Seco watershed, where the Pines Fire occurred, is approximately $42 \mathrm{~km}^{2}$ and has elevations ranging from 426 to $1,820 \mathrm{~m}$ above sea level. Due to its elevation, the Arroyo Seco experiences relatively high precipitation $(840 \mathrm{~mm} /$ year) compared with the Los Angeles basin ( $375 \mathrm{~mm} /$ year). Vegetation in the upper Arroyo Seco, and at the study sites, is primarily chaparral, with coniferous forests in limited regions of the uppermost part of the watershed. Soils are poorly developed and are underlain by mainly igneous rock including granite, tonalite, gneiss, granodiorite, and to a lesser extent, siliceous metasedimentary rocks, and alluvial deposits (Department of Conservation of California 1998). The soil texture at the sampling locations were determined to be sandy loam and gravelly sandy loam.

Soil samples were collected at four burned sites (ASB1-4) and one unburned site (ASUB1) within the Arroyo Seco watershed during October of 2006, prior to the first post-fire storm. All burned soil sites were collected within $500 \mathrm{~m}$ of each other; primary vegetation (prior to burning) was chaparral. Site descriptions are as follows: ASB1 and ASB2 were both collected from moderate severity burn areas. ASB3 and ASB4 were collected from areas of low to moderate burn severity. Pre-fire vegetation density was moderate at ASB1 and ASB4, while ASB2, ASB3, and ASUB1 (collected on a nearby hillside) were characterized by dense patches of chaparral. At each site, debris (twigs and large pieces of litter or charred wood) was removed; steep-sided pits were dug, and soils were collected from $0-13-\mathrm{cm}$ depths at $2.5-\mathrm{cm}$ intervals, with approximately $50 \mathrm{~g}$ of soil collected at each depth interval. THg and TOC analyses were performed on soils collected from each depth interval.

\subsubsection{Piru Creek Watershed (Day Fire)}

The Day Fire, which started on September 4, 2006, and was contained by October 13, 2006, burned for over a month and consumed $660 \mathrm{~km}^{2}$ (Table 1). The burned region is approximately 70 miles north of the city Los Angeles and is almost entirely within National Forest lands (Los Padres and Los Angeles) in the Transverse Mountain Range (Fig. 1). Approximately $50 \%$ of the $512 \mathrm{~km}^{2}$ Piru Creek watershed was burned during the Day Fire, with Piru Creek serving as the northern fire boundary. Piru Creek watershed feeds into Pyramid Reservoir, a storage system for imported water from the California State Water Project, which provides drinking water for the Los Angeles metropolitan region. Mean annual precipitation in the region is approximately $480 \mathrm{~mm} /$ year. Chaparral is the dominant vegetation, but the watershed's high relief (elevations ranging from 792 to $2,690 \mathrm{~m}$ ) and Mediterranean climate allow for a wide range of vegetation to exist (Scott et al. 1968). The geology is characterized by pre-Cretaceous igneous and metamorphic basement rock, overlain by thick sedimentary sequences of Eocene marine sandstones and conglomerates with interbedded shales (Scott et al. 1968). Soils are generally shallow and of coarse texture (Scott et al. 1968). The soil texture at sampling locations was determined to be sandy loam.

Soil samples were collected from a network of burned and unburned locations within the Piru Creek watershed on a seasonal basis (Table 2). This watershed is primarily composed of National Forest lands with very limited access by road; therefore, sampling was conducted in the eastern portion of the watershed, corresponding to the location of the California Department of Water Resources stream 
Table 2 Piru Creek Watershed (Day Fire) sampling sites with temporal sampling frequency. "PCB" 1-6 represent the burned sites and "PCUB" $1-2$ represent the unburned sites. $L$ and $M$ stand for light and moderate burn severity. F06, W07, S07, F08, and W08 refer to the seasonal sampling periods defined in the text

\begin{tabular}{|c|c|c|c|c|c|c|c|c|}
\hline \multirow[t]{2}{*}{ Site } & \multirow[t]{2}{*}{ Burn Severity } & \multirow{2}{*}{$\begin{array}{l}\text { F06 } \\
\text { Nov-06 }\end{array}$} & \multicolumn{2}{|l|}{ W07 } & \multicolumn{2}{|l|}{ S07 } & \multirow{2}{*}{$\begin{array}{l}\text { F07 } \\
\text { Nov-07 }\end{array}$} & \multirow{2}{*}{$\begin{array}{l}\text { W08 } \\
\text { Feb-08 }\end{array}$} \\
\hline & & & Jan-07 & Mar-07 & Jun-07 & Jul-07 & & \\
\hline \multicolumn{9}{|l|}{ Burned } \\
\hline PCB1 & $\mathrm{L}$ & $X$ & & & $\mathrm{X}$ & & $X$ & $X$ \\
\hline PCB2 & $\mathrm{M}$ & $\mathrm{X}$ & & & $\mathrm{X}$ & & $X$ & $\mathrm{X}$ \\
\hline PCB3 & $\mathrm{M}$ & & $X$ & & & & & $X$ \\
\hline PCB4 & $\mathrm{M}$ & & $\mathrm{X}$ & & $X$ & & $\mathrm{X}$ & $X$ \\
\hline PCB5 & $\mathrm{M}$ & & $\mathrm{X}$ & & $\mathrm{X}$ & & $X$ & $X$ \\
\hline PCB6 & $\mathrm{M}$ & & $X$ & & & & & $X$ \\
\hline \multicolumn{9}{|l|}{ Unburned } \\
\hline PCUB1 & & & $\mathrm{X}$ & & & $\mathrm{X}$ & $\mathrm{X}$ & $\mathrm{X}$ \\
\hline PCUB2 & & & & $\mathrm{X}$ & & $\mathrm{X}$ & $X$ & $X$ \\
\hline
\end{tabular}

gage (Fig. 1, insert). The primary vegetation at all of the burned sites was chaparral (prior to burning), and vegetation density was similar at each site. At the unburned sites, chaparral was the dominant vegetation type, but sage scrub and juniper were also present. Limited access only allowed for initial soil collection from two sites (PCB1, PCB2) on November 17, 2006 (F06), prior to the first storm. Over the subsequent 2006-2007 rainy season (February/March, W07), soil samples were collected from four additional burned sites (PCB3-6) and two unburned sites along Piru Creek (PCUB1, PCUB2). Soil sites were revisited during the summer (June/July) of 2007 (S07) and again in the fall (November) of 2007 (F07), 1 year following the initial sampling date (Table 2). Soils were sampled again at the end of the 2007-2008 winter rainy season (February/March; W08; Fig. 2).
When revisiting the sampling sites, soils were collected $<0.50 \mathrm{~m}$ from the original location. Site homogeneity was verified on the W08 sampling dates by collecting and analyzing triplicate depth profiles at the vertices of a $1 \mathrm{~m}$ unilateral triangle (three sites total). Because of the minimal rainfall $(\sim 130 \mathrm{~mm})$ and little change in surface conditions in the winter of 2007, soils collected during the fall of 2006 and winter of 2007 were grouped together for subsequent comparisons and are referred to henceforth as F06/ W07 (Table 2). For each site, surface debris was removed; steep-sided pits were dug, and soils were collected from $0-13 \mathrm{~cm}$ depths at $2.5-\mathrm{cm}$ intervals, with approximately $50 \mathrm{~g}$ of soil collected at each depth interval. Samples were collected at each depth interval for $\mathrm{THg}$ and TOC analysis as well as for grain-size fractionation and related $\mathrm{THg}$ analysis.
Fig. 2 Day Fire (Piru Creek Watershed) sampling collection for designated seasons (November 2006February 2008). Collection dates (triangles) are shown relative to timing of storm events, with streamflow shown on the left $y$-axis (cubic meter per second) and precipitation shown on the right $y$-axis (millimeter)

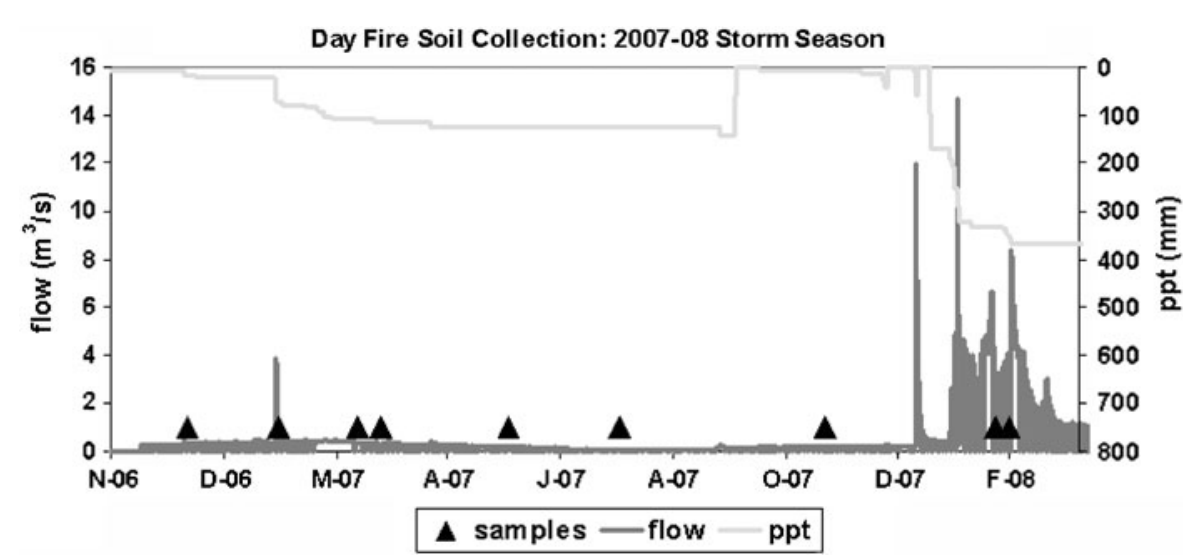




\subsection{Analytical Methods}

\subsubsection{Soil Mercury Content}

Soil total Hg was measured by dual-stage gold amalgamation/cold vapor atomic fluorescence spectrometry, in accordance with EPA Method 7473, using a Milestone Direct Mercury Analyzer (DMA-80) (US EPA 2002a). The regression coefficient of the daily calibration curves consistently exceeded 0.99 and recovery of standard reference material estuarine sediment (IAEA 405) was consistently within $20 \%$ of the established value. Soil sample aliquots of $\sim 500 \mathrm{mg}$ were measured in triplicate or additionally until the relative standard deviation (ratio between standard deviation and mean) was below 0.30 . The mean of the triplicate measurements (nanogram $\mathrm{Hg}$ per gram) is reported as well as the standard deviation ( \pm nanogram per gram) for all samples.

\subsubsection{Soil Organic Content}

TOC was determined by loss on ignition (LOI) and derived as a percentage of dry weight. Approximately $1 \mathrm{~g}$ of soil was weighed into a pre-burned crucible. The dry weight of the soil was recorded after $12 \mathrm{~h}$ in a $105^{\circ} \mathrm{C}$ oven. The sample was then heated in a $550^{\circ} \mathrm{C}$ furnace for $1 \mathrm{~h}$, cooled, and reweighed to determine TOC (percent organics).

\subsubsection{Soil Fractionation}

Soil samples from the Piru Creek watershed (2006 Day Fire) were also size-fractionated at each depth interval prior to $\mathrm{THg}$ analysis. Typically, grain-size fractions at the clay/silt break or at the fine/very fine sand break have shown the highest correlations to trace metal concentrations and have been used to normalize data sets from different sampling locations (Horowitz and Erlick 1987; Loring 1991). However, it has also been shown that, in sandy soils lacking sufficient organic material, $\mathrm{Hg}$ preferentially sorbs to the coarse mineral soil (Biester et al. 2002). In the current study, soil was fractionated into gravel $(>2 \mathrm{~mm})$, coarse sand (0.50-2 mm), medium sand (0.25-0.5 mm), and fine sand $(<0.25 \mathrm{~mm})$ according to the USDA NRCS grain-size classification scheme (USDA Natural Resource Conservation Service 1993). Separation of grain sizes less than $0.25 \mathrm{~mm}$ was not undertaken for $\mathrm{Hg}$ analysis due to risk of sample contamination. Silt and clay were included with the fine sand; this aggregated soil fraction was termed "fines." All soil samples were weighed, covered, and air-dried for a 10-day period. Any large clumps of soils were then crushed using acidwashed utensils. The soil was placed in an acid-washed, polypropylene micro-sieve set and shaken for $10 \mathrm{~min}$ at $140 \mathrm{rpm}$ using a mechanical shaker. The sieved soil fraction was transferred to a pre-tared acid-washed environmental sampling bottle and reweighed. The total $\mathrm{Hg}$ content of the coarse sand, medium sand, and fines fractions (and composite sample) was measured to determine the distribution of $\mathrm{Hg}$ on varying particle sizes for each depth interval. A bulk sample (at each depth interval and integrated over all sampling depths) was also processed in a similar manner and measured for total $\mathrm{Hg}$.

\subsubsection{Leaching}

The USGS field leach test (Hageman and Briggs 2000) was used to analyze $\mathrm{Hg}$ leaching on soils collected from two of the Day Fire sites within Piru Creek watershed, one unburned (PCUB2) and one burned (PCB6). Three grams of soil were used due to sample quantity limitations. Representative samples of burned and unburned soils were sieved into two groups: fines $(<0.25 \mathrm{~mm})$ and composite $(<2 \mathrm{~mm})$, resulting in four groups (unburned fines/composite and burned fines/ composite). Of the soil material that passed through the sieves $(0.25 \mathrm{~mm}, 2 \mathrm{~mm})$, portions were set aside for measurement of $\mathrm{THg}$ (following EPA method 7473 described above) and TOC by LOI (section 3.2) (US EPA 2002a). The $3 \mathrm{~g}$ of soil was weighed into an acid-washed Teflon bottle, to which $60 \mathrm{ml}$ of the reagent water $(18 \mathrm{M} \Omega)$ was added. The mixture was shaken vigorously for $2 \mathrm{~h}$ in a "wrist agitator" and subsequently filtered (0.45um pore size) using an acid-washed syringe. For each of the four groups, duplicate experiments were performed. In order to determine initial concentration of $\mathrm{Hg}$ in the soil samples, all four groups were analyzed using the Milestone Direct Mercury Analyzer (DMA-80; section 3.1).

Total $\mathrm{Hg}$ analysis was performed on the filtered solution using the Total Hg system by Brooks Rand in accordance with EPA Method 1631, Revision E (US EPA 2002b). This method allows for the determination of $\mathrm{Hg}$ at a minimum level of $0.5 \mathrm{ng} \mathrm{Hg} / \mathrm{L}$. A sample aliquot was transferred to Teflon-coated bottles, reduced with stannous chloride $\left(\mathrm{SnCl}_{2}\right)$ to convert $\mathrm{Hg}$ (II) to volatile $\operatorname{Hg}(0)$, and purged with Argon, allowing the 
volatile $\operatorname{Hg}(0)$ to be transported to gold-coated sand traps. The gold-coated sand traps were then heated for $3 \mathrm{~min}$ to $450-500^{\circ} \mathrm{C}$ to allow desorption of $\mathrm{Hg}$. Argon gas passed through the trap at a flow rate of $30 \mathrm{ml} / \mathrm{min}$ to transport the $\mathrm{Hg}$ (II) to the cold vapor fluorescence spectrometer, where an absorbance peak was recorded. All samples were measured in triplicate, and the regression coefficient $\left(\mathrm{R}^{2}\right)$ for daily calibration curves consistently exceeded 0.99 . Percent soil leaching was calculated using the following formula:

$\%$ Leached $=\frac{(\text { Hg_liquid }) \times 60 \mathrm{ml}}{(\text { Hg_soil }) \times 3 g} \times 100 \%$

where $\mathrm{Hg}$ is total mercury measured in the leachate (liquid, <0.45-um fraction) and soil; $60 \mathrm{ml}$ is the amount of reagent water added, and $3 \mathrm{~g}$ is the amount of soil analyzed.

\subsubsection{Data Analysis}

Analysis of variance was used to compare differences in $\mathrm{Hg}$ concentrations and TOC between groups (study areas, seasonal sampling periods, and grain sizes). The analysis was performed using the anoval function of the Matlab computing program (Mathworks Inc. 2005), with F-tests and $p$ values used as a guide to determine significance at the $5 \%$ level.

\section{Results and Discussion}

\subsection{Regional Comparison}

\subsubsection{Soil Mercury Concentrations:}

Due to differences in the sampling regimes between the three burn areas, the regional comparison was limited to soils collected immediately post-fire and to the mean $\mathrm{Hg}$ concentrations and organic content of these soils. Bulk soil total $\mathrm{Hg}$ (hereafter noted as $\mathrm{Hg}$ ) concentrations for burned soils at the Malibu Creek watershed (2005 Topanga Fire, MB1-4), averaged over both the 2.5- and 10-cm depth intervals $(n=14)$ ranged from 1 to $37 \mathrm{ng} \mathrm{Hg} / \mathrm{g}$, with an average concentration of $17 \mathrm{ng}$ $\mathrm{Hg} / \mathrm{g}( \pm 12 \mathrm{ng} / \mathrm{g}$; Fig. 3). Average organic content of the samples was measured $9.4 \%$ TOC $( \pm 4.4 \%$; Fig. 3$)$.

Bulk soil $\mathrm{Hg}$ concentrations for burned soil sites in the Arroyo Seco watershed (2006 Pines Fire, ASB1-4),

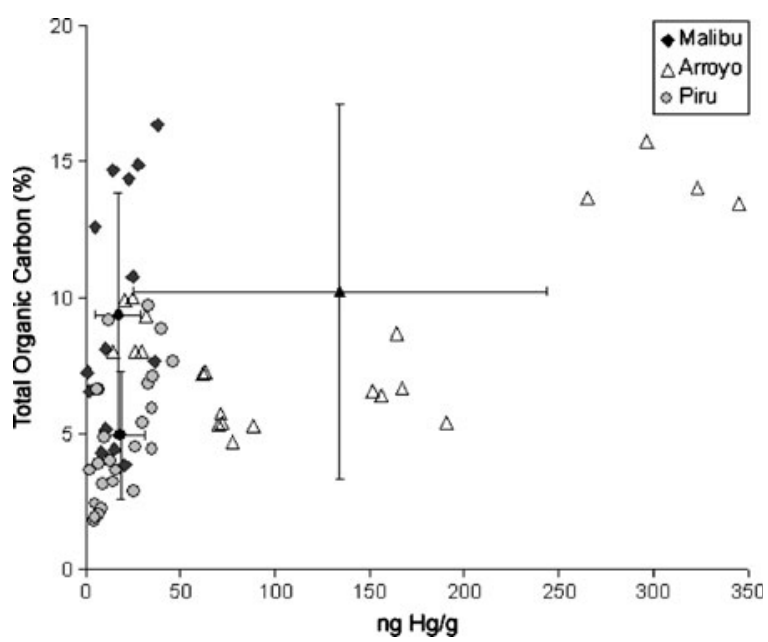

Fig. 3 Scatter plot of Total Organic Carbon (percent) vs. Hg (nanogram $\mathrm{Hg}$ per gram) in each of the three study areas: Malibu (dark gray diamonds), Arroyo Seco (white triangles), and Piru Creek (light gray circles). The solid shapes correspond to the data symbols with the same shape and error bars show the mean values (center symbol) and standard deviation at each site

averaged over the entire $15.0-\mathrm{cm}$ depth profile, ranged from 14 to $349 \mathrm{ng} \mathrm{Hg} / \mathrm{g}$, with an average concentration of $134 \mathrm{ng} \mathrm{Hg} / \mathrm{g}( \pm 109 \mathrm{ng} \mathrm{Hg} / \mathrm{g}, n=24)$, and average organic content of $10.2 \%$ TOC $( \pm 6.9 \%, n=24$; Fig. 3$)$. The unburned soil site (ASUB1) exhibited lower average $\mathrm{Hg}$ concentrations with a value of $92 \mathrm{ng} \mathrm{Hg} / \mathrm{g}$ ( $\pm 46 \mathrm{ng} \mathrm{Hg} / \mathrm{g}, n=6$ ), ranging from 51 to $176 \mathrm{ng} \mathrm{Hg} / \mathrm{g}$. Average organic content in the unburned soils was measured at $17.2 \%$ TOC $( \pm 14.3 \%, n=6)$.

Bulk soil $\mathrm{Hg}$ concentrations of the burned soils of Piru Creek Watershed (2006 Day Fire, PCB1-6, F06/ W07 sampling period), averaged over the entire $15.0 \mathrm{~cm}$ depth profile, ranged from 2 to $44 \mathrm{ng} \mathrm{Hg} / \mathrm{g}$, with an average of $18.5 \mathrm{ng} \mathrm{Hg} / \mathrm{g}( \pm 12.9 \mathrm{ng} \mathrm{Hg} / \mathrm{g}, n=25)$, and low organic content was exhibited in the burned soils of Piru Creek (4.9\% TOC; $\pm 2.4 \%, n=25$; Fig. 3 ). In the unburned Piru Creek soils, Hg concentrations ranged from 4 to $67 \mathrm{ng} \mathrm{Hg} / \mathrm{g}$, with an average of $19.0 \mathrm{ng} \mathrm{Hg} / \mathrm{g}$ $( \pm 19.8 \mathrm{ng} \mathrm{Hg} / \mathrm{g}, n=12)$. Very low organic content was measured in the unburned soils in Piru Creek $(2.7 \%$ TOC; $\pm 1.3 \%, n=12$ ) soils in comparison to the unburned soils. Our results appear counterintuitive; however, a metadata analysis made by Johnson and Curtis (2001) found increases in soil organic matter in soils affected by wildfire, attributed to the accumulation of charcoal and hydrophic organic matter resistant to chemical and biological degradation. Additionally, due to the size and proximity of the Day Fire, the unburned 
soils were collected either across the creek or $\sim 2 \mathrm{~km}$ upstream, of the burned sites, and it is possible that site heterogeneity contributed to the lower TOC observed in the unburned sites of Piru Creek Watershed.

Mercury levels varied greatly between the three study areas. Proximity to anthropogenic contaminants (L.A. Basin) appears to have an impact on observed soil $\mathrm{Hg}$ concentrations, which are significantly $(p<0.05)$ higher in the Arroyo Seco soils than in the other two sites. Both the Malibu and Piru sites (which show similar $\mathrm{Hg}$ levels) are located north of the urban/metropolitan center, and regional winds carry urban pollutants inland and away from these regions. These sites exhibit $\mathrm{Hg}$ concentrations that are consistent with previously published values in natural, semi-arid systems, such as a Nevada desert wildfire site with measured values of $47.4 \mathrm{ng} / \mathrm{g}( \pm 26.8 \mathrm{ng} \mathrm{Hg} / \mathrm{g})$ and $49.4 \mathrm{ng} \mathrm{Hg} / \mathrm{g}( \pm 11.3 \mathrm{ng}$ $\mathrm{Hg} / \mathrm{g}$ ) of $\mathrm{Hg}$ in unburned and burned soils, respectively (Engle et al. 2006). The Arroyo Seco, on the other hand, exhibited $\mathrm{Hg}$ concentrations that are more comparable to $\mathrm{Hg}$ measured in more humic soils, such as peat bogs in northwestern Ontario where Mailman and Bodalay (2005) measured $\mathrm{Hg}$ concentrations of $162 \mathrm{ng} / \mathrm{g}( \pm 132$ ng $\mathrm{Hg} / \mathrm{g}$ ) or even contaminated areas such as those reported by Palmieri et al. (2006), where soil Hg concentrations ranged from 90 to $1230 \mathrm{ng} \mathrm{Hg} / \mathrm{g}$ at a site draining an abandoned cinnabar $(\mathrm{HgS})$ mine. The Arroyo Seco experienced a much smaller, more confined fire in comparison to Malibu Creek and Piru Creek Watersheds, it is possible that lower loss rates contributed to the higher $\mathrm{Hg}$ concentrations observed in the burned soils at this site. The upper Arroyo Seco also receives more rain than the other study areas due to topography and related orographic effects, which may also impact vegetation density. However, similar burn severities were observed in all three study locations. In addition, TOC measurements from the sampled Arroyo Seco sites were in the same range as those observed in the Malibu sites (both were significantly higher than the Piru Creek soil TOC; $p<0.05$; Fig. 3). Hence, we hypothesize that the primary factor effecting elevated soil $\mathrm{Hg}$ concentrations is the location/proximity to anthropogenic (urban) sources.

\subsubsection{Soil Mercury Depth Profiles}

Depth profiles were collected at both the Arroyo Seco (Pines fire) and Piru Creek (Day fire) watersheds. All of the Arroyo Seco profiles and two of the Piru Creek profiles (PCB1 and PCB2) were collected prior to any post-fire rainfall; the remaining Piru Creek profiles were collected after the 2007 rainy season had begun. However, the combination of the watershed's antecedent conditions (dry), the extremely low rainfall totals during the first wet season (ash and charred soil were observed at the burned soil surface) and the similar behavior of these profiles to that observed in the prestorm samples led to their inclusion in the analysis.

Of the nine burned soil profiles collected in the first season after the fire, eight profiles exhibited lower $\mathrm{Hg}$ concentrations at the soil surface $(0.0-2.5$ $\mathrm{cm})$ than at the next depth interval $(2.5-5.0 \mathrm{~cm})$, with the only exception being Day Fire site PCB1 (Fig. 4). The PCB1 site was estimated to have been burned with light severity (using dNBR and field observations) and was also located next to a trail (subject to disturbance). The remaining sites in both study areas were burned with moderate severity (estimated using dNBR and verified by field observations). In contrast to the burned soil profiles, the three unburned soil profiles (Arroyo Seco site AS-UB and Day Fire sites PCUB1 and PCUB2) exhibited the highest $\mathrm{Hg}$ concentrations at the soil surface (Fig. 4). The observed low $\mathrm{Hg}$ concentrations at the soil surface following wildfire is consistent with other studies of $\mathrm{Hg}$ in burned soils and was observed in both the Hg-enriched soils of the Arroyo Seco and the soils of Piru Creek watershed (Mailman and Bodaly 2005; Engle et al. 2006).

Several of the freshly burned depth profiles, from both the Piru Creek and Arroyo Seco locations, exhibited the highest $\mathrm{Hg}$ concentrations and TOC measurements between depths of 2.5 and $7.5 \mathrm{~cm}$ (Fig. 4). Volatilization of organic matter during fire can move these compounds from the soil surface (in vegetation and litter) to the subsurface where they condense, coating mineral particles and forming a hydrophobic horizon (DeBano 1981; Johnson and Curtis 2001; González-Pérez et al. 2004). Wildfires also affect the chemical properties of soil organic matter and can lead to the formation of pyromorphic humus, which has been shown to change to promote the fixing of polyvalent metals (Giovanni and Lucchesi 1983; Giovanni et al. 1987). Field measurements of WDPT revealed hydrophobicity in all of the burned Arroyo Seco soils at the 2.5-5.0 and 5.0-7.5-cm depth intervals. In the Piru Creek soils, WDPT at the moderate burn severity site sampled prior to the first storm, as well as at one of the burned sites sampled following the winter 2007 storm, also indicated soil hydrophobicity in the $2.5-7.5 \mathrm{~cm}$ range. 


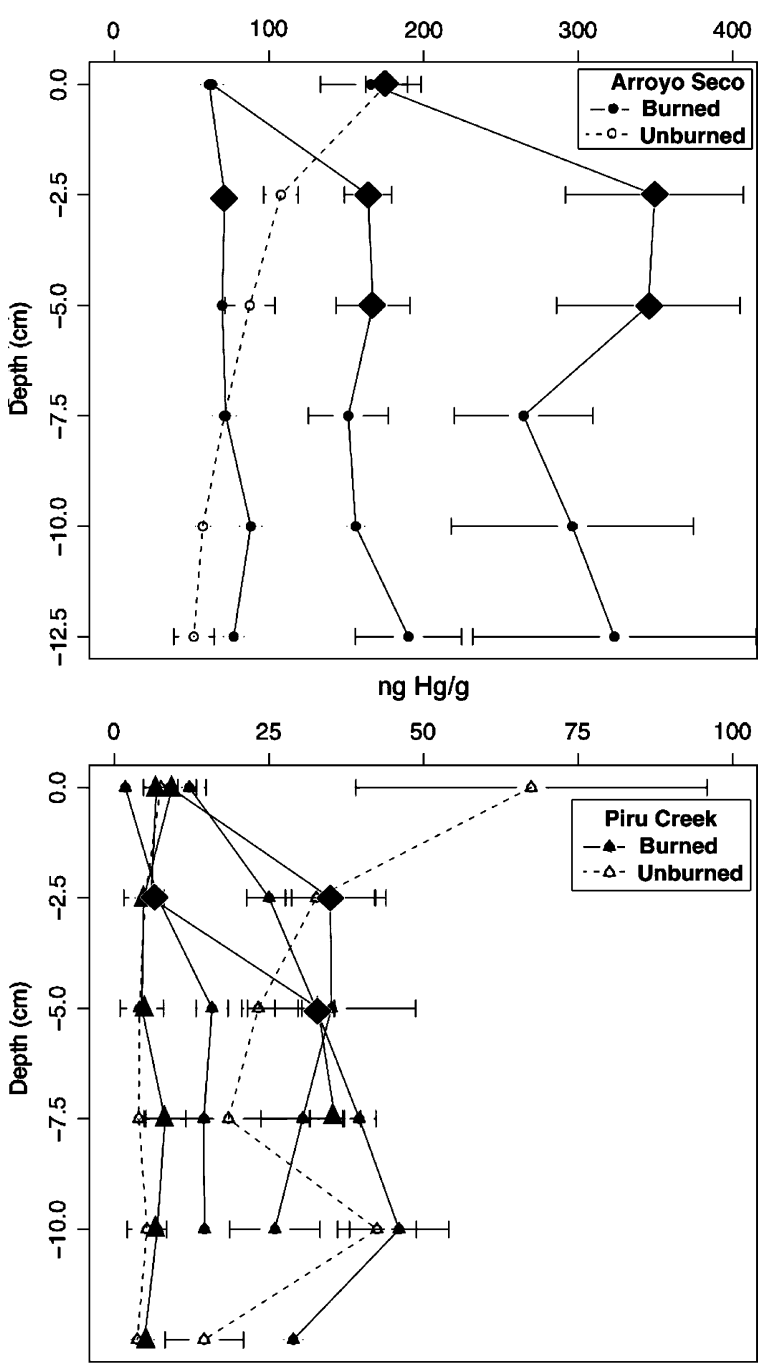

$\mathrm{ng} \mathrm{Hg} / \mathrm{g}$

Fig. 4 Soil depth profiles of $\mathrm{Hg}$ concentrations in burned (solid line) and unburned (dashed) soils at both Piru Creek (triangles) and Arroyo Seco (circles) watersheds, collected in the first season following the fire. The large solid triangles on the Piru Creek plot indicate the two burned sites that were sampled prior to the first post-fire storm event. The large diamonds indicate observed soil hydrophobicity. Note the scale difference between the two study locations

\subsection{Piru Creek Watershed (Day Fire)}

\subsubsection{Soil Mercury Concentration Profile: Temporal Analysis}

In general, the low surface $\mathrm{Hg}$ levels in first post-fire (F06/W07) Piru Creek sampled sites were accompanied by similar behavior in the corresponding soil organic matter (Fig. 5), supporting previously reported studies of volatilization of surface $\mathrm{Hg}$ during the fire. As mentioned above, PCB1 did not exhibit lower $\mathrm{Hg}$ concentrations when compared with the $2.5-5.0-\mathrm{cm}$ depth interval, and its light burn severity is evidenced in the corresponding high organic matter levels in the surface soil of this site (Fig. 5). The two unburned sites (PCUB1 and PCUB2) exhibited significantly different behavior than the burned sites (and from each other) with respect to surface $\mathrm{Hg}$ and organic matter levels during the W07 sampling period $(p<0.05)$. Site PCUB1 exhibited the highest surface $\mathrm{Hg}$ concentrations $(67.4 \mathrm{ng} \mathrm{Hg} / \mathrm{g}( \pm 28.4 \mathrm{ng} \mathrm{Hg} / \mathrm{g}))$ of all of the Piru Creek sites on the initial sampling date, yet low levels of surface organic matter were observed (1.7\% SOM). Other studies have observed increased $\mathrm{Hg}$ concentrations in throughfall in areas impacted by wildfire, and we hypothesize that the location of the PCUB1 site may have been subject to enhanced deposition of particulate $\mathrm{Hg}$ during the Day Fire (Witt et al. 2009). This site was located beneath chaparral and juniper canopy, and the higher surface $\mathrm{Hg}$ concentrations (and low surface TOC) may reflect $\mathrm{Hg}$ contribution in the throughfall during the winter 2007 storm.

In order to quantify seasonal changes in soil $\mathrm{Hg}$ concentrations and TOC measurements, while accounting for spatial variability between sampling locations, we compared the percent change to determine if there was a significant difference in these constituents between sampling events. Over the subsequent dry seasons (S07 and F07), the average surface $\mathrm{Hg}$ concentration of the burned soils increased by $417 \%( \pm 72 \%)$ from the initial sampling date, with the mean $\mathrm{Hg}$ of the dry season burned soil surface significantly higher than the initial measurements $(p<0.05)$. This is exemplified in the surface $\mathrm{Hg}$ concentrations of the two moderately burned sites for which we had complete temporal sampling (PCB2, PCB4; Fig. 5). By the F07 sampling date, the surface soils of $\mathrm{PCB} 2$ and $\mathrm{PCB} 4$ showed $\mathrm{Hg}$ concentrations $50-70 \mathrm{ng} / \mathrm{g}$ higher than those measured 1 year previously (Fig. 5). In the case of PCB4, increased $\mathrm{Hg}$ values were accompanied by increased TOC over the summer and fall of 2007; the higher $\mathrm{Hg}$ concentrations and TOC at this site may be related to vegetation recovery following the fire. The slight increase in organic matter observed at PCB2 is not sufficient to explain the high $\mathrm{Hg}$ concentrations observed at the soil surface and throughout the depth 

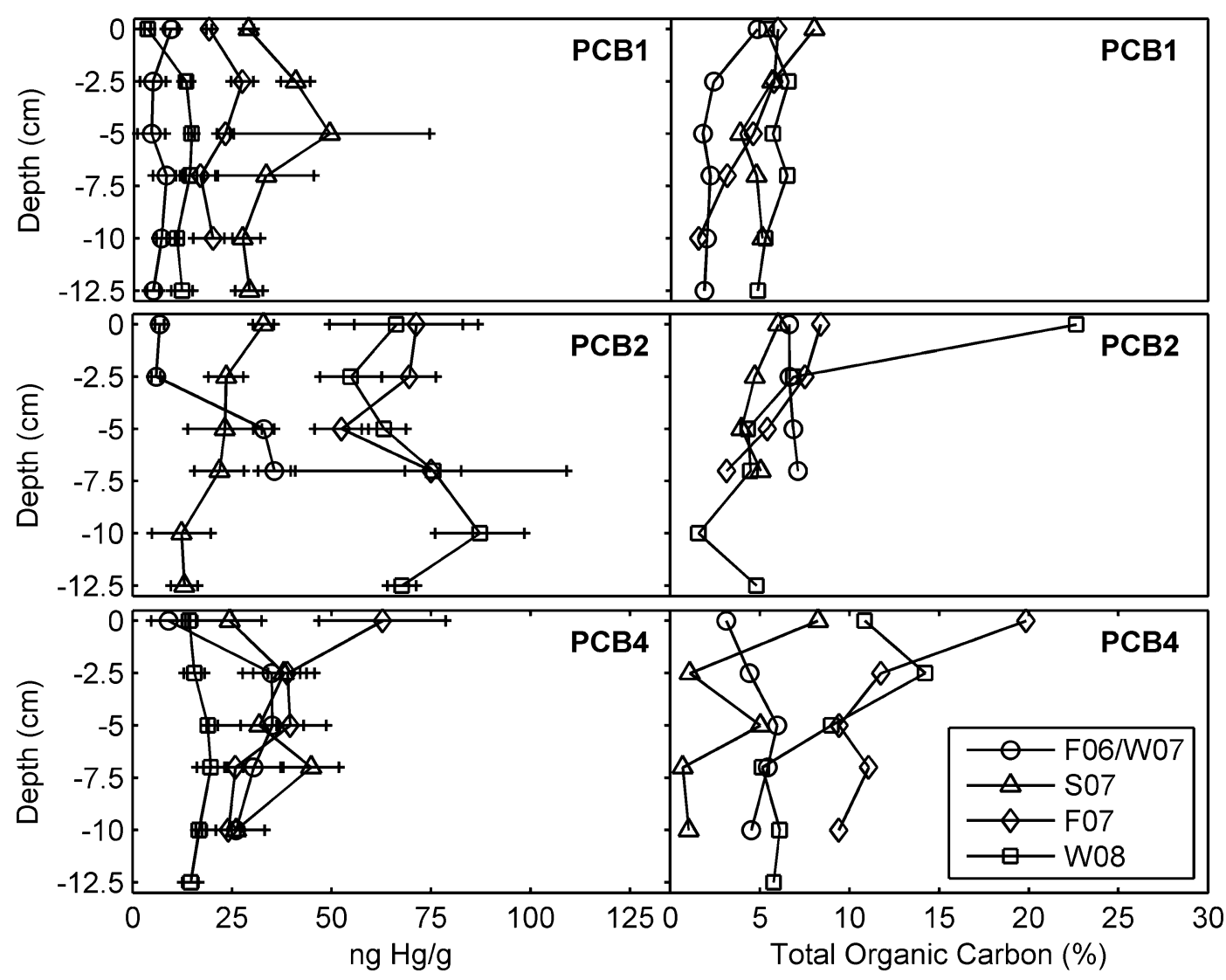

Fig. $5 \mathrm{Hg}$ concentration profiles (left) and TOC profiles (right) of the Piru Creek burned sites: PCB1 (top row), PCB2 (middle row), and PCB4 (bottom row). A circle, triangle, diamond, and

profile on the F07 sampling date. The surface soils at these sites were charred, and we hypothesize that the burned soils in the Piru watershed have been chemically altered, with the pyromorphic humus acting as an activated carbon to more efficiently sequester and retain $\mathrm{Hg}$, contributing to higher observed $\mathrm{Hg}$ concentrations in the first year following the fire (Giovanni and Lucchesi 1983; Giovanni et al. 1987; González-Pérez et al. 2004). The light burn severity site (PCB1) also exhibited higher organic matter accompanied by higher $\mathrm{Hg}$ concentrations in the surface soils in the dry season following the fire (S07, F07; Fig. 5).

Site PCUB1 appears to stabilize by the S07 and F07 sampling dates; the high surface $\mathrm{Hg}$ concentrations observed during the initial sampling (F06/ W07) were not observed again. Little change was observed in both the $\mathrm{Hg}$ concentration and TOC profiles at PCUB1 over the dry season (Fig. 6). Similar TOC and $\mathrm{Hg}$ concentration profiles (low) square are used to represent F06/W07, S07, F07, and W08 sampling dates, respectively

were observed at PCUB2. Of note is that neither unburned site experienced the sharp increase in $\mathrm{Hg}$ concentration that was observed in the moderately burned soil surfaces (PCB2 and PCB4) over the postfire period, nor the increased soil $\mathrm{Hg}$ concentrations throughout the depth profile as observed in sites PCB1 and PCB2.

Compared with the first winter season rainfall (130 $\mathrm{mm})$, precipitation during the winter of 2007-2008 (370 mm) was closer to normal (480 mm/year). Given the low rainfall totals, little soil erosion was noted in the first winter season. However, on the W08 sampling date, considerable surface erosion was observed at the field sites, including sheet-flow, rill and gully erosion, and collapsed banks. Additionally, the winter rains of 2008 initiated vegetation re-growth in the Piru Creek Watershed. Moderate vegetative recovery was observed on the W08 sampling date and is reflected in the increased surface TOC measure- 
Fig. $6 \mathrm{Hg}$ concentration profiles (left) and TOC profiles (right) of the Piru Creek unburned sites: PCUB1 (top row) and PCUB (bottom row). A circle, triangle, diamond, and square are used to represent F06/W07, S07, F07, and W08 sampling dates, respectively

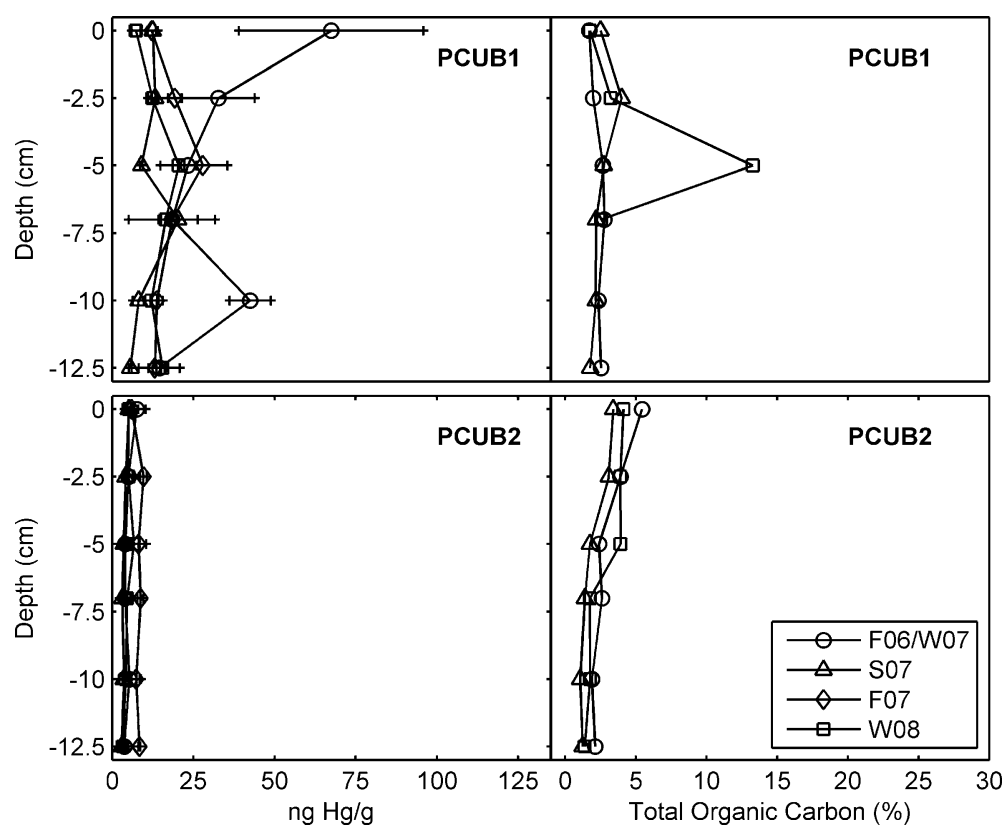

ments in burned soils on this sampling date. Most sites (burned and unburned) exhibited lower $\mathrm{Hg}$ concentrations at the surface during the winter of 2008 in comparison to the previous dry seasons (Fig. 5). A $16 \%$ $( \pm 54 \%)$ decrease was observed in the mean surface $\mathrm{Hg}$ concentration of the burned sites from the previous season, and a $24 \%( \pm 6 \%)$ decrease was observed in the unburned soils. This was a significant change for the burned soil sites which had previously shown a gain in $\mathrm{Hg}$ over the dry seasons $(p<0.05)$. We attribute the low surface $\mathrm{Hg}$ concentrations observed at most sites during the W08 sampling period to soil flushing and enhanced erosion at the disturbed (burned) sites and hypothesize that while TOC increased as the pre-fire vegetation began to return, the $\mathrm{Hg}$ that had accumulated in the surface soils was generally flushed or carried off with eroded sediment. The enhanced erosion observed following the winter 2008 may also have resulted in a slight shift in some of the vertical profiles.

\subsubsection{Soil Organic Content}

A comparison of the seasonal $\mathrm{Hg}$ concentrations and organic matter levels of the burned and unburned surface soils profiles (all burned soil sites PCB1PCB6 and unburned sites PCUB1 \& PCUB2, surface composite samples, $0.0-2.5$ and $2.5-5.0-\mathrm{cm}$ depth intervals; Fig. 7). Recovery of vegetation following the wildfire is reflected in the steady increase in organic matter in surface soils over the subsequent seasons. Soil $\mathrm{Hg}$ concentrations were initially low on the W07 sampling date and increased over the following dry season sampling period (S07, F07), reflecting the observed TOC increase (as evidenced in the burned site PCB4). Increasing soil Hg concentrations that were not accompanied by increased TOC where also observed (PCB2), indicating possible chemical changes in the soil organic matter. The drop in the mean $\mathrm{Hg}$ concentration in the burned soils from W08 was not accompanied by lower TOC values. In fact, the highest observed TOC values were from W08 sampling period, supporting our hypothesis that the lower levels of $\mathrm{Hg}$ were most likely due to transport away from the study sites during the winter storms of 2008. For the unburned soil sites (PCUB1 \& PCUB2), little change was observed seasonally in the surface organic content. The high initial $\mathrm{Hg}$ (W07) concentrations at PCUB1 were not reflected in the TOC values. However, these $\mathrm{Hg}$ concentrations dropped by the following season and, like the TOC values, remained relatively constant throughout the following year.

\subsubsection{Mercury and Grain-Size Fractionation}

For the burned soils of Piru Creek watershed (all soil samples, integrated over the entire depth profile) 
Fig. 7 Boxplots representing the seasonal $\mathrm{Hg}$ concentrations at the soil surface $(0$ and 2.5 -cm depth intervals) for the burned (top, left; $n=10$ : F06/ W07, F07, and 8: S07, and 12: W08) and unburned sites (top, right ( $n=4:$ F06/W07, S07, F07, and 3: W08)) and seasonal surface TOC levels in both burned (bottom, left $(n=10:$ F06/W07, S07, 8: F07, 12: W08)) and unburned soils (bottom, right $(n=4$ : F06/W07, S07, W08; 0: F07)) within Piru Creek watershed. Top and bottom edge of each box represents the 75 th and 25 th percentile, respectively; the line bisecting the box represents the median; circles are outliers
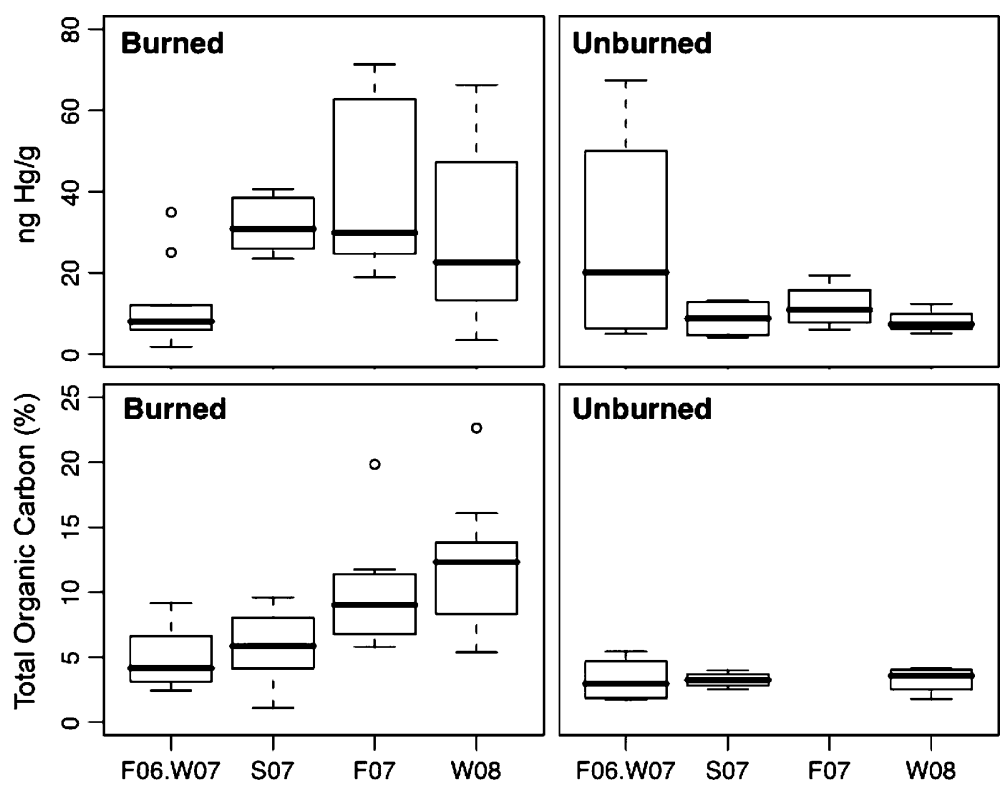

$41.94 \%( \pm 19.75 \%), 18.88 \%( \pm 4.68 \%)$, and $39.19 \%$ $( \pm 19.90 \%)$ of the soil was classified as fine, medium, and coarse grain-size fractions, respectively $(n=76$; Fig. 8). Significantly higher concentrations of $\mathrm{Hg}$ were observed in the fine and medium grain-size fractions than observed in the coarse fraction $(p<$ 0.05; Fig. 8). Overall $\mathrm{Hg}$ distribution in the burned soils included $37.19 \%( \pm 5.54 \%)$ in the fines, $35.43 \%$ $( \pm 4.68 \%)$ in the medium fraction, and $27.38 \%$ $( \pm 5.51 \%)$ in the coarse grain-size fraction $(n=76)$. Significantly lower $\mathrm{Hg}$ concentrations were observed in the coarse grain-size fraction than in the medium and fine-grained burned soils of Piru Creek $(p<0.05)$.

The grain-size distribution in the unburned soils (all soil samples, integrated over the entire depth profile) was similar to that observed in the burned soils with $40.92 \%( \pm 9.49 \%), 26.26 \%( \pm 9.42 \%)$, and $32.82 \%$ ( $\pm 9.93 \%)$ of the soil measured as fine, medium, and coarse grain-size fractions, respectively $(n=35)$. $\mathrm{Hg}$ distribution in the unburned soils included $53.70 \%$ $( \pm 13.92 \%), 29.47 \%( \pm 9.71 \%)$, and $16.83 \%( \pm 7.68 \%)$ in the fine, medium, and coarse grain size fractions, respectively $(n=35)$. Hg appears to be preferentially bound to the fines in the unburned soils of Piru Creek, with $\mathrm{Hg}$ concentrations decreasing as the grain size increased (Fig. 8). Hg concentrations were significantly different in each of the fractions $(p<0.05)$.

Others have observed a trend towards coarser soil texture following fire, attributed to heat-induced aggre- gation of silt and clay particles as well as the introduction of particulate charcoal fractions from litter combustion (González-Pérez et al. 2004). The variability of the $\mathrm{Hg}$ distribution within the different grain-size fractions between the burned and unburned soils of Piru Creek is likely a function of multiple factors, including site characteristics (such as native geology, slope, land cover, etc.) as well as fire-induced changes to soil aggregates and soil organic matter. Additional laboratory experiments on $\mathrm{Hg}$ binding in pre- and postfire samples are needed to better clarify the effects of fire on $\mathrm{Hg}$ distribution within soil fractions.

\subsubsection{Leaching}

Similar to previous research, leaching of soil $\mathrm{Hg}$ was minimal (Grigal 2002). Laboratory leach tests showed this to be the case in both the burned and unburned samples. In both cases, more $\mathrm{Hg}$ was leached from the bulk sample $(<2 \mathrm{~mm})$ than from the fine grain-size fraction $(<0.25 \mathrm{~mm})$. In the burned bulk samples, $23.25 \mathrm{ng} \mathrm{Hg} / \mathrm{g}( \pm 1.49)$ soil was measured in the soil and $0.48 \mathrm{ng} \mathrm{Hg} / \mathrm{g}( \pm .0 .12)$ soil was detected in the equivalent leachate, hence $2.07 \%( \pm 0.34 \%) \mathrm{Hg}$ leached from the burned bulk sample (Table 3). In the fines, $36.49 \mathrm{ng} \mathrm{Hg} / \mathrm{g}( \pm 3.82)$ was measured in the soil and $0.21 \mathrm{ng} \mathrm{Hg} / \mathrm{g}( \pm 0.08)$ soil measured in the equivalent leachate, resulting in only $0.58 \%( \pm 0.07 \%)$ $\mathrm{Hg}$ leached from the fines in the burned samples 
Fig. 8 Boxplots representing percent of soil $\mathrm{Hg}$ measured in each grain-size fraction (top) and the grainsize distribution of the soil (bottom) for both burned ( $n=76$ for each grain-size fraction) and unburned $(n=35$ for each grain-size fraction) soils within Piru Creek watershed. Top and bottom edge of each box represents the median; circles are outliers. The coarse, medium, and fines fractions are defined as 0.50-2 mm, 0.25-0.50 mm, and $<0.25 \mathrm{~mm}$, respectively
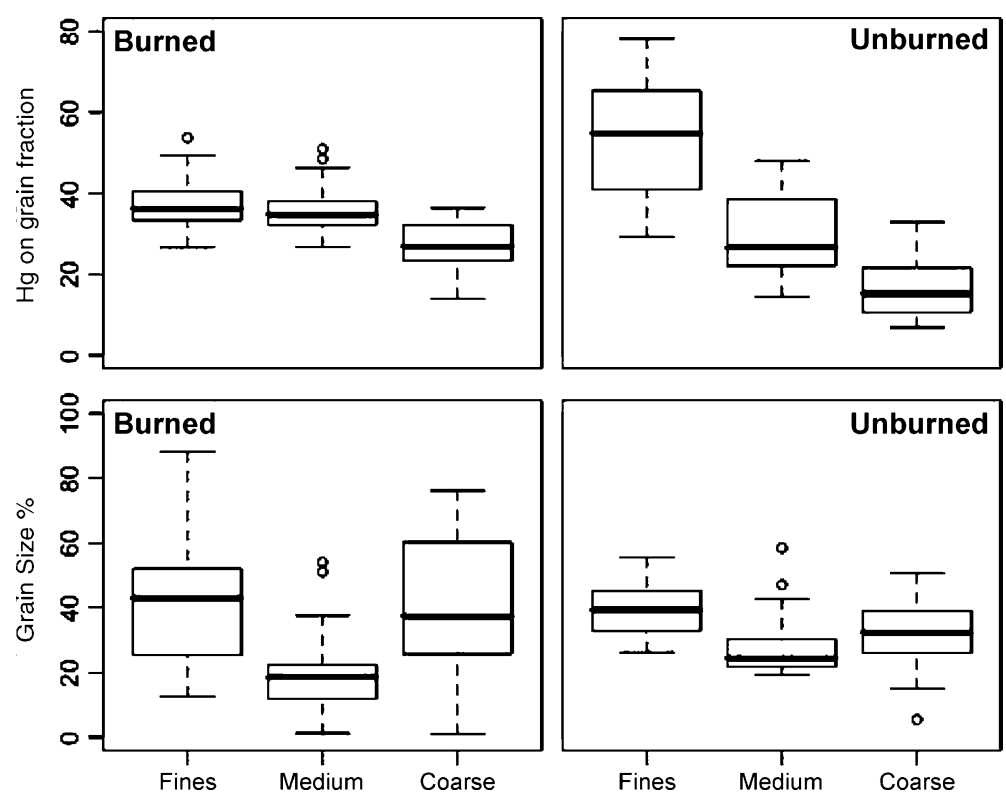

(Table 3). The unburned bulk samples contained 4.25 ng $\mathrm{Hg} / \mathrm{g}( \pm 0.48)$ soil with $0.11 \mathrm{ng} \mathrm{Hg} / \mathrm{g}( \pm 0.01)$ soil measured in the equivalent leachate. Therefore, $3.07 \%$ $( \pm 0.70) \mathrm{Hg}$ leached from the bulk sample (Table 3). In the unburned fines, $11.58 \mathrm{ng} \mathrm{Hg} / \mathrm{g}( \pm 1.35)$ was measured in the soil with $0.09 \mathrm{ng} \mathrm{Hg} / \mathrm{g}( \pm 0.01)$ soil observed in the equivalent leachate, hence $0.82 \%$ $( \pm 0.08 \%) \mathrm{Hg}$ leached from the fine grain-size fractions of the unburned soil (Table 3). In general, the composite samples leached more $\mathrm{Hg}$ than the fines samples for both burned $(274 \%$ more $\mathrm{Hg}$ leached from composite than fines) and unburned soils (257\% more $\mathrm{Hg}$ leached from composite). However, these data support that $\mathrm{Hg}$ not volatilized in the fire may be in a more recalcitrant form, such as complexed to a more resistant form of organic matter (pyromorphic

Table 3 Piru Creek Watershed (Day Fire) leaching data

\begin{tabular}{lllllll}
\hline & \multicolumn{2}{l}{ Burned: } & & \multicolumn{2}{l}{ Unburned: } \\
\cline { 2 - 3 } & Bulk & Fines & & Bulk & Fines \\
\hline [Hg] Soil (ng Hg/g soil): & 23.25 & 36.49 & & 4.25 & 11.58 \\
{$[\mathrm{Hg}]$ Leachate (ng Hg/g soil): } & 0.48 & 0.21 & & 0.11 & 0.09 \\
$\% \mathrm{Hg}$ leached & 2.07 & 0.07 & & 3.07 & 0.82 \\
\hline
\end{tabular}

"Bulk" refers to the bulk soil sample $(<2.0 \mathrm{~mm})$ prior to grainsize fractionation. "Fines" refers to the $<0.25$ grain-size fraction containing fine sand, silt, and clay humus) which developed as a result of the fire, as 41$48 \%$ more $\mathrm{Hg}$ was leached from the unburned than the burned samples, seen in both the fine and composite samples (González-Pérez et al. 2004).

\section{Summary and Concluding Remarks}

Results from this work support previous published studies that show a loss of $\mathrm{Hg}$ in freshly burned soils (Friedli et al. 2003b; Engle et al. 2006). However, the current study expands upon previous results to include observations of soil $\mathrm{Hg}$ as a watershed recovers from fire. To summarize, the freshly burned soils exhibited lowest concentrations of $\mathrm{Hg}$ at the soil surface (top 0.0 $2.5 \mathrm{~cm}$ ) in all but one of the nine sampling sites burned to moderate severity. The only burned soil profile that did not exhibit this behavior was subject to low burn severity, highlighting the importance of burn severity on $\mathrm{Hg}$ mobilization during wildfires. In the three unburned soils sites, the highest $\mathrm{Hg}$ concentrations were observed at the soil surface. This behavior was observed both in the Piru Creek watershed, located in a remote location, where the background $\mathrm{Hg}$ levels ( 2 to $87 \mathrm{ng} \mathrm{Hg} / \mathrm{g}$ ) were characteristic of a natural, semi-arid region, and in the enriched soils of the Arroyo Seco watershed, where $\mathrm{Hg}$ concentrations of $>300 \mathrm{ng} \mathrm{Hg} / \mathrm{g}$ were observed.

The impact of fire on organic carbon also plays an important role in soil $\mathrm{Hg}$ dynamics. A few of the 
freshly burned depth profiles exhibited the highest $\mathrm{Hg}$ concentrations between depths of 2.5 and $7.5 \mathrm{~cm}$, with the highest TOC and hydrophobicity also measured in this range. Following the initial volatilization of $\mathrm{Hg}$ at the soil surface during wildfire, the burned soils experienced an accelerated accumulation of $\mathrm{Hg}$ following the fire. In the Piru Creek watershed soils, a four-fold increase in mean surface soil $\mathrm{Hg}$ concentrations was observed over the subsequent dry season, corresponding to an increase in the mean surface TOC measurements as well as moderate vegetative recovery. However, the relationship is not straightforward, as one of the burned sites exhibited much higher soil $\mathrm{Hg}$ concentrations 1 year after the fire with only a slight increase in organic material. We hypothesize that heat-induced changes in soil organic matter resulting from the fire allowed the charred surface soils to more efficiently complex and retain atmospheric $\mathrm{Hg}$. Additional investigations are needed to better understand $\mathrm{Hg}$ sorption in burned soils.

Following the second post-fire rainy season, low surface $\mathrm{Hg}$ concentrations were observed in the burned and unburned sites, while the organic content of the burned soils continued to increase as the watershed's vegetation began to return. We attribute the loss of $\mathrm{Hg}$ in at the soil surface to soil flushing and enhanced erosion (observed) during the winter storms. These results underscore that the observed accelerated accumulation of $\mathrm{Hg}$ in the burned soils, along with elevated potential of erosion, could result in increased delivery of organic- or particulate-bound $\mathrm{Hg}$ to surface waters. And, depending upon precipitation patterns, this risk may extend beyond the first post-fire rainy season and persist in the years following the fire.

Our grain-size distribution analysis supports that a range of grain-size fractions (not only the fine fraction) need to be considered in soil $\mathrm{Hg}$ analysis (Biester et al. 2002). Hg-soil partitioning with respect to grain size was not as strong in the burned soils as in the unburned soils (where $\mathrm{Hg}$ preferentially bound to the finer soils). As the time since burning increases, an evolution towards the transport of more coarse sediments occurs in post-fire storm runoff (Desilets et al. 2007). Our results indicate that this coarser material may also be more likely to contain higher concentrations of soilbound $\mathrm{Hg}$. Although leaching was minimal in both the burned and unburned soils, the difference in $\mathrm{Hg}$ leaching between the fine and more coarsely grained soil fractions indicates that coarsely grained soils must also be considered for their potential to contribute to $\mathrm{Hg}$ mobilization in burned watersheds.

The current study provides a unique look at soil$\mathrm{Hg}$ interactions immediately after wildfire as well as several post-fire seasons. The accelerated accumulation of $\mathrm{Hg}$ observed in the burned soils of Piru Creek watershed, along with observed differences in $\mathrm{Hg}$-soil partitioning within the grain-size fractions in burned and unburned soils, underscores the need for extended water quality monitoring of post-fire watersheds. We advocate that this is especially critical in areas that are subject to high rates of atmospheric deposition of contaminants or above essential water supply systems. Results from this study also raise important questions regarding the mechanisms controlling $\mathrm{Hg}$ binding in burned soils, including the role of translocated organic matter in $\mathrm{Hg}$ sequestration and retention and in the grain-size distribution of $\mathrm{Hg}$ following fire.

Acknowledgements Funding for the current work has been supported by NSF Hydrologic Sciences (SGER EAR \#0707162), NSF BES Career Grant (BES \#0348783), the University of California Toxics and Substances Research and Teaching Program (UCTSR\&TP), the University of California's Leadership Excellence through Advanced Degrees (UC LEADS), the National Institute of Health's Minority Access to Research Careers (MARC), and the NIH/NSF UCLA Center for Academic Research and Excellence (CARE) at UCLA. We thank Chu-Ching Lin, Christina Zabalza, Helen Jung, Alicia Kinoshita, Paul Kirchner, Lauren Tomita, and numerous other volunteers who assisted with field campaigns as well as in sample and laboratory processing. We also thank the anonymous reviewers for their insightful comments and suggestions, which were helpful for improving our manuscript.

Open Access This article is distributed under the terms of the Creative Commons Attribution Noncommercial License which permits any noncommercial use, distribution, and reproduction in any medium, provided the original author(s) and source are credited.

\section{References}

Ambrose, R. F., \& Orme, A. R. (2000). Lower Malibu Creek and Lagoon resource enhancement and management: final report to the California State Coastal Conservancy. Los Angeles: University of California.

Amirbahman, A. R., Ruck, P. L., Fernandez, I. J., Kahl, J. S., \& Haines, T. A. (2004). The effect of fire on mercury cycling in the soils of forested watersheds: Acadia National Park, Maine, USA. Water, Air, and Soil Pollution, 152, 313-331.

Babiarz, C. L., Hurley, J. P., Benoit, J. M., Shafer, M. M., Andren, A. W., \& Webb, D. A. (1998). Seasonal influences on partitioning and transport of total and 
methylmercury in rivers from contrasting watersheds. Biogeochem, 41, 237-257.

Barco, J., Hogue, T. S., Curto, V., \& Rademacher, L. (2008). Linking hydrology and stream geochemistry in urban fringe watersheds. Journal of Hydrology, 360, 31-47.

Beeson, P. C., Martens, S. N., \& Breshears, D. D. (2001). Simulating overland flow following wildfire: mapping vulnerability to landscape disturbance. Hydrological Processes, 15, 2917-2930.

Biester, H., Muller, G., \& Scholer, H. F. (2002). Binding and mobility of mercury in soils contaminated by emissions from chlor-alkali plants. Science of the Total Environment, 284, 191-203.

Biswas, A., Blum, J. D., Klaue, B., \& Keeler, G. J. (2007). Release of mercury from Rocky Mountain forest fires. Global Biogeochemical Cycles, 21, GB1002. doi:10.1029/ 2006GB002696.

Blake, W. H., Walsh, M. J., Barnsley, G. P., Dyrynda, P., \& James, J. G. (2003). Heavy metal concentrations during storm events in a rehabilitated industrialized catchment. Hydrological Processes, 17, 1923-1939.

Brunke, E. G., Labuschagne, C., \& Slemr, F. (2001). Gaseous mercury emissions from a fire in the Cape Peninsula, South Africa, during January 2000. Geophysical Research Letters, 28, 1483-1486.

Bushey, J. T., Driscoll, C. T., Mitchell, M. J., Selvendiran, P., \& Montesdeoca, M. R. (2008). Mercury transport in response to storm events from a northern forest landscape. Hydrological Processes. doi:10.1002/hyp.7091.

Caldwell, C. A., Canavan, C. M., \& Bloom, N. S. (2000). Potential effects of forest fire and storm flow on total mercury and methylmercury in sediments of an arid-lands reservoir. Science of the Total Environment, 260, 125-133.

Cannon, S. H., \& Reneau, S. L. (2000). Conditions for generation of fire-related debris flows, Capulin Canyon, New Mexico. Earth Surface Processes and Landforms, $25,1103-1121$.

Cannon, S. H., Powers, P. S., \& Savage, W. Z. (1998). Firerelated hyperconcentrated and debris flows on Storm King Mountain, Glenwood Spring, Colorado USA. Environmental Geology, 35, 210-217.

Cannon, S. H., Bigio, E. R., \& Mine, E. (2001). A process for fire-related debris-flow initiation, Cerro Grande fire New Mexico. Hydrological Processes, 15, 3011-3023.

CDFFP. California Department of Forestry and Fire Protection (2007) Annual Report. Office of California State Fire Marshall.

Chorover, J., Vitousek, P. M., Everson, A. A., Esperanza, A. M., \& Turner, D. (1994). Solution chemistry profiles of mixed-conifer forests before and after fire. Biogeochem, 26, 115-144.

DeBano LF (1981) Water repellent soils: a state of the art, Gen. Tech. Rpt. PSW-46. USDA For. Serv., Pacific Southwest Forest and Range Exp. Sta., Berkeley, CA, 21pp

Department of Conservation of California (1998) Division of mines and geology. Seismic hazard zone report for the Pasadena 7.5-minute quadrangle. Los Angeles County, California.

Desilets, S. L. E., Nijssen, B., Ekwurzel, B., \& Ferré, T. P. A. (2007). Post-wildfire changes in suspended sediment rating curves: Sabino Canyon, Arizona. Hydrological Processes, 21, 1413-1348.
Dicosty, R. J., Callaham, M. A., \& Stanturf, J. A. (2006). Atmospheric deposition and re-emission of mercury estimated in a prescribed forest-fire experiment in Florida, USA. Water, Air and Soil Pollution, 176, 77-91.

Engle, M. A., Gustin, M. S., Johnson, D. W., Murphy, W. W., Walker, R. F., Wright, J., et al. (2006). Mercury distribution in two Sierran forest and one desert sagebrush steppe ecosystems and the effects of fire. Science of the Total Environment, 367, 222-233.

Friedli, H. R., Radke, L. F., \& Lu, J. Y. (2001). Mercury in smoke from biomass fires. Geophysical Research Letters, 28, 3223-3226.

Friedli, H. R., Radke, L. F., Lu, J. Y., Banic, C. M., Leaitch, W. R., \& MacPherson, J. I. (2003). Mercury emissions from burning of biomass from temperate North American forests: laboratory and airborne measurements. Atmospheric Environment, 37, 253-267.

Friedli, H. L., Radke, L. F., \& Prescott, R. (2003). Mercury emissions from the August 2001 wildfires in Washington State and an agricultural waste fire in Oregon and atmospheric mercury budget estimates. Global Biogeochemical Cycles, 17.2, 1-8.

Gabet, E. J. (2003). Post-fire thin debris flows: sediment transport and numerical modeling. Earth Surface Processes and Landforms, 28, 1341-1348.

Giovannini, G., \& Lucchesi, S. (1983). Effect of fire on hydrophobic and cementing substances of soil aggregates. Soil Science, 136, 231-236.

Giovannini, G., Lucchesi, S., \& Giachetti, M. (1987). The natural evolution of burned soil: a three-year investigation. Soil Science, 143, 220-226.

González-Pérez, J. A., González-Vila, F. J., Almendros, G., \& Heike, K. (2004). The effect of fire on soil organic mattera review. Environment International, 30(6), 855-870.

Grigal, D. F. (2002). Inputs and outputs of mercury from terrestrial watersheds: a review. Environmental Review, 10, $1-39$.

Gustin, M. S., \& Ladwig, K. (2004). An assessment of the significance of mercury release from coal fly ash. Journal of the Air \& Waste Management Association, 54, 320-330.

Hageman, P. L., Briggs, P. H. (2000). A simple field leach test for rapid screening and qualitative characterization of mine waste dump material on abandoned mine lands. Proceedings of the 5th International Conference on Acid Rock Drainage II; Desborough, GA, pp 1463-1475.

Harden, J. W., Neff, J. C., Sandberg, D. V., Turetsky, M. R., Ottmar, R., Gleixner, G., et al. (2004). Chemistry of burning the forest floor during the FROSTFIRE experimental burn, interior Alaska, 1999. Global Biogeochemical Cycles, 18, GB3014. doi:10.1029/2003GB002194.

Horowitz, A. J., \& Erlick, K. A. (1987). The relation of stream sediment surface area, grain size and composition to trace element chemistry. Applied Geochemistry, 2, 437-451.

Hurley, J. P., Benoit, J. M., Babiarz, C. L., Shafer, M. M., Andren, A. W., Sullivan, J. R., et al. (1995). Influences of watershed characteristics on mercury levels in Wisconsin rivers. Environmental Science \& Technology, 29, 18671875.

Johnson, D. W., \& Curtis, P. S. (2001). Effects of forest management on soil $\mathrm{C}$ and $\mathrm{N}$ storage: meta analysis. Forest Ecology and Management, 140, 227-238. 
Jung, H. Y., Hogue, T. S., Rademacher, L. K., \& Meixner, T. (2009). Impact of wildfire on source water contributions in Devil Creek, CA: evidence from end-member mixing analysis. Hydrological Processes, 23(2), 183-200.

Keeley, J. E., \& Zedler, P. H. (2009). Large, high-intensity fire events in southern California shrublands: debunking the fine-grain age-patch model. Ecological Applications, 19, 69-94.

Kelly, E. N., Schindler, D. W., St. Louis, V. L., Donald, D. B., \& Vladicka, K. E. (2006). Forest fire increases mercury accumulation by fishes via food web restructuring and increased mercury inputs. PNAS, 103(51), 19380-19385.

Key CH, Benson NC (2006) Landscape assessment: Ground measure of severity, the Composite Burn Index; and Remote sensing of severity, the Normalized Burn Ratio. In Lutes DC, Keane RE, Caratti JF, Key CH, Benson NC, Sutherland S, Gangi LJ 2006. FIREMON: Fire Effects Monitoring and Inventory System. USDA Forest Service, Rocky Mountain Research Station, Ogden, UT. Gen. Tech. Rep. RMRS-GTR-164-CD: LA 1-51.

Lawson, N., \& Mason, R. (2001). Concentration of mercury, methylmercury, cadmium, lead, arsenic, and selenium in the rain and stream water of two contrasting watersheds in western Maryland. Water Research, 35, 4039-4052.

Letey, J. (1969). Measurement of contact angle, water drop penetration time, and critical surface tension. In L. F. Debano \& J. Letey (Eds.), Proceedings of a symposium on water repellant soils, 6-10 May, 1968 (pp. 43-47). Riverside, CA: University of California.

Loring, D. H. (1991). Normalization of heavy-metal data from estuarine and coastal sediments. Science, 48, 101-115.

Mailman, M., \& Bodaly, R. A. (2005). Total mercury, methyl mercury, and carbon in fresh and burned plants and soil in Northwestern Ontario. Environmental Pollution, 138, 161-166.

Mason, R. P., \& Sullivan, K. A. (1998). Mercury and methylmercury transport through an urban watershed. Water research, 32, 321-330.

Mast, M. A., \& Clow, D. W. (2008). Effects of 2003 wildfires on stream chemistry in Glacier National Park, Montana. Hydrological Processes. doi:10.1002/hyp.7121.

Meixner, T., Fenn, M., Wohlgemuth, P., Oxford, M., \& Riggan, P. (2006). N saturation symptoms in chaparral catchment are not reversed by prescribed fire. Environmental Science \& Technology, 40, 2887-2894.

Moody, J. A., \& Martin, D. A. (2001). Initial hydrologic and geomorphic response following a wildfire in the Colorado Front Range. Earth Surface Processes and landforms, 26, 1049-1070.

Morales, H. A., Navar, J., \& Dominguez, P. A. (2000). The effect of prescribed burning on surface runoff in a pine forest stand of Chihuahua, Mexico. Forest Ecology and Management, 137, 199-207.

Olson, E. S., Miller, S. J., Sharma, R. K., Dunham, G. E., \& Benson, S. A. (2000). Catalytic effects of carbon sorbents for mercury capture. Journal of Hazardous Materials, 74, 61-79.

Palmieri, H. E. L., Nalini, H. A., Jr., Leonel, L. V., Windmoller, C. C., Santos, R. C., \& de Brito, W. (2006). Quantification and speciation of mercury in soils from the Tripuí Ecological Station, Minas Gerais, Brazil. Science of the Total Environment, 368, 69-78.
Pierson, F. B., Robichaud, P. R., Moffet, C. A., Spaeth, K. E., Hardegree, S. P., Clark, P. E., et al. (2008). Fire effects on rangeland hydrology and erosion in a steep sagebrushdominated landscape. Hydrological Processes, 22, 2916-2929.

Ravichandran, M. (2004). Interactions between mercury and dissolved organic matter: a review. Chemosphere, 55, 319-331.

Rulli, M. C., \& Rosso, R. (2007). Hydrologic response of upland catchments to wildfires. Advances in Water Resources, 30, 2072-2086.

Scott, K. M., Ritter, J. R., \& Knott, J. M. (1968). Sedimentation in the Piru Creek Watershed, southern California. U.S. Geol. Surv. Water-Supply Pap. 1798-E; 48 p.

Sigler, J. M., Lee, X., \& Munger, W. (2003). Emission and long-range transport of gaseous mercury from a large-scale Canadian boreal forest fire. Environmental Science \& Technology, 37, 4343-4347.

Soil Survey Division Staff (1993). Soil survey manual. Soil Conservation Service. U.S. Department of Agriculture Handbook 18

Stephens, C. L., Meixner, T., Poth, M., McGurk, B., \& Payne, D. (2005). Prescribed fire, soils, and stream water chemistry in a watershed in the Lake Tahoe Basin, California. International Journal of Wildland Fire, 13, 27-35.

Ullrich, S. M., Tanton, T. W., \& Abdrashitova, S. A. (2001). Mercury in the aquatic environment: a review of factors affecting methylation. Critical Reviews in Environmental Science and Technology, 31, 241-293.

USDA Natural Resource Conservation Service (2007). Soil survey of Santa Monica Mountains National Recreation Area.

US EPA (2002a). Method 7473, Mercury in solids and solutions by thermal decomposition, amalgamation and atomic absorption spectrophotometry. Washington, D.C.

US EPA (2002b). Method 1631, Revision E: Mercury in water by oxidation, purge and trap, and cold vapor atomic fluorescence spectrometry. Washington, D.C.

US EPA (2007) California's final 2004-06 303(d) List-water quality limited segments being addressed by USEPA approved TMDLs. Washington, DC

Westerling, A. L., \& Bryant, B. P. (2008). Climate change and wildfire in California. Climate Change, 87(Suppl 1), S231-S249. doi:10.1007/s10584-007-9363-Z.

Westerling, A. L., Hidalgo, H. G., Cyan, D. R., \& Swetnam, T. W. (2006). Warming and earlier spring increase Western U.S. wildfire activity. Science, 313, 940-943.

Whitlock, C. (2004). Forests, fires and climate. Nature, 432, 28-29.

Whyte, D. C., \& Kirchner, J. W. (2000). Assessing water quality impacts and cleanup effectiveness in streams dominated by episodic mercury discharges. Science of the Total Environment, 260, 1-9.

Wiedinmeyer, C., \& Friedli, H. (2007). Mercury emission estimates from fires: an initial inventory for the United States. Environmental Science \& Technology, 41, 8092-8098.

Witt, E. L., Kolka, R. K., Nater, E. A., \& Wickman, T. R. (2009). Forest fire effects on mercury deposition in the boreal forest. Environmental Science \& Technology, 43(6), 1776-82.

Wondzell, S. M., \& King, J. G. (2003). Post fire erosional processes in the Pacific Northwest and Rocky Mountain regions. Forest Ecology and Management, 178, 75-87. 